\title{
Architecture of tourist and leisure facilities on the Kłodzko-Orlice borderland, on the example of Zieleniec and Lasówka
}

\author{
Jacek Suchodolski \\ jacek.suchodolski@pwr.edu.pl \\ Faculty of Architecture of Wroctaw University of Science and Technology
}

\begin{abstract}
On the Kłodzko-Orlice borderland on the Dzika Orlica river, regional architecture had a great influence on the form and character of the tourist and recreation facilities built there until 1945. After the Second World War many of these buildings ceased to exist. The new ones do not refer to the rich heritage of the region, as evidenced by the architecture and construction details of guest houses, holiday homes, villas or inns in Zieleniec and Lasówka the best developing locations of the region today, but largely devoid of regional character.
\end{abstract}

Key words: architecture, region, Kłodzko-Orlice borderland, tourism

\section{Preface}

In the Dzika Orlica Valley in the Kłodzko Land among the settlements located on its banks, whose post-war fate was different and many of them were significantly depopulated, the tourist function is currently developing best in Zieleniec and Lasówka. Situated upriver, next to each other, they are characterized by different terrain conditions. The steeply inclined slopes of Šerlich and Orlica belonging to the Orlickie mountains, where Zieleniec is located, contrast with the relatively smoothly sloping planes of the mid-mountain meadows of the Bystrzyckie Mountains, where Lasówka spreads. So there are favorable conditions for the development of winter and summer sports of various types and the possibility to choose the appropriate forms of recreation. The common element connecting the two locations in the sphere of architecture, as well as other in the Kłodzko Land, was certainly the form of regional, wooden buildings, residential buildings as well as those associated with tourism which were built here until 1945.

Today, unfortunately, these houses are becoming scarcer and newly built ones are usually characterized by a foreign form and style, or hardly successfully refer to the rich cultural heritage of the region. It is particularly visible and important in places of touristic value which, being a kind of a showcase for the whole region, should stand out with their architecture, including that of regional origin.

\section{Zieleniec; history, development of tourist and leisure facilities}

One of the most famous holiday resorts in the Kłodzko Land with very good conditions for sports, especially winter sports is Zieleniec. This small settlement of woodcutters, shepherds and folk involved in iron ore mining and smelting, once lost in the forest intervals of the Bystrzyckie and Orlickie Mountains, transformed already at the end of the second half of the $19^{\text {th }}$ century into a well-developed ski resort. The establishment of Zieleniec dates back to 1719 , when only 20 people lived there, and at the end of the $18^{\text {th }}$ century there were 50 houses and a small church. With time Zieleniec grew, so that at the end of the $19^{\text {th }}$ century there were more 
than 80 buildings, a school, a forester's lodge, a wilderness hut, water mills, a sawmill, a limestone quarry with a lime kiln, and a furnace for iron smelting together with a forge (14). The majority of buildings there were wooden buildings of regional origin, located in small groups, on the hills surrounding the center of the village. In 1779 on the top of Orlica, the dominant mountain over Zieleniec, a platform from which one could observe the surroundings [Photo 1].
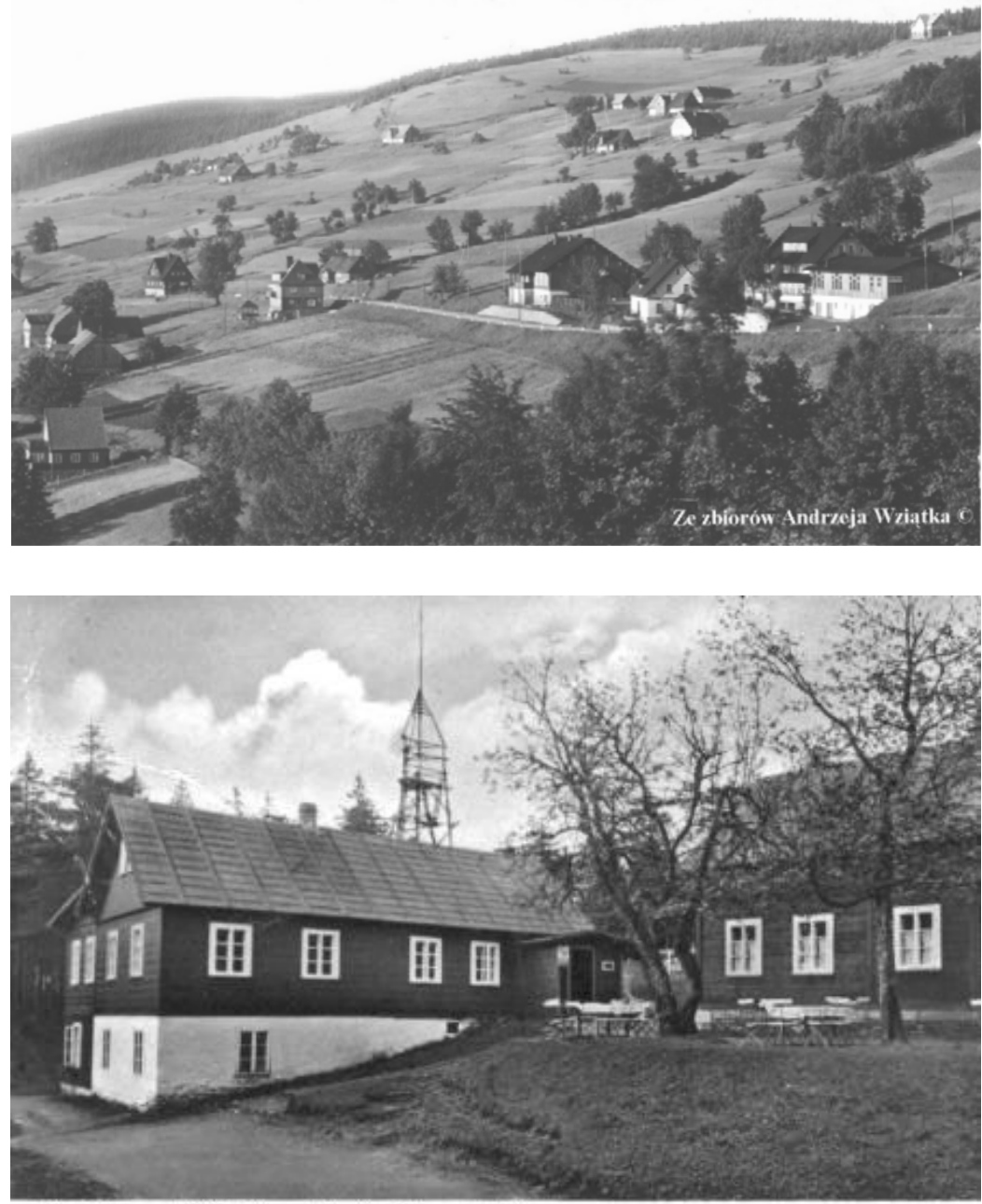

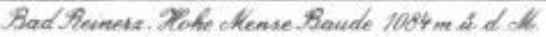

Fig. 1. A view of Zieleniec from north- western side Interwar period. In the foreground - Adlerbaude hostel and school in Zieleniec. The characteristic scattered buildings of this village are visible. Source: from Andrzej Wziątek's collection.

Widok Zieleńca od strony pn.-zach. Lata międzywojenne. Na pierwszym planie schronisko Adlerbaude i szkoła w Zieleńcu. Widoczna charakterystyczna rozproszona zabudowa tej miejscowości. Źródło: ze zbioru Andrzeja Wziątka.

Fig. 2. Photo 2 Orlica. Hoche Mense Baude Hostel with observation tower* Interwar period. Source: www. dolny.slask.org.pl

Orlica. Schronisko Hoche Mense Baude z wieżą widokową** Lata międzywojenne. Źródło: www.dolny. slask.org.pl

* Destroyed after 1945 complex of buildings with an observation tower, just below the summit of Orlica, the place where Heinrich Rübarsch settled, is an irreparable loss for tourism in the region. The construction of a lookout tower within the framework of the border cooperation between Poland and the Czech Republic will certainly improve this situation and at the same time re-evaluate the tourist values of Orlica. It will be one of several to be built on the Polish-Czech border.

** Zniszczony po 1945 roku zespół budynków z wieżą widokową, miejsce w którym osiadł Heinrich Rủbarsch, tuż pod szczytem Orlicy, jest niepowetowaną stratą dla turystyki w tym regionie.

Heinrich Rübartsch was of great importance for the further fate of this little-known location lost in the border forests. Born in Niwa near Polanica-Zdrój, after returning from the army in the 1870s he settled in Zieleniec and initially ran an inn, "Gasthaus zur Mense", located opposite the church. In the eighties he started his activity, also as a mountain guide guiding tourists, mainly from Duszniki through the Orlica massif, ending the tour on the top of this mountain. Unfortunately, the trees growing there obscured the view and at first Rübartsch hung rope ladders on trees, offering more athletic patients this kind of admiring the unfolding views. In 1881, the authorities of the GGV in Duszniki approached Rübartsch with a proposal to build a wooden observation 
tower. Half financed by him, it was built as a 16-meter structure with three viewing platforms (19). In 1883 a small cottage was built at its foot, which became the forerunner of the future "Hohe Mense - Baude" shelter. Due to the increasing tourist attendance, the shelter was extended after a year, so that it consisted of two rooms, a vestibule, kitchen and attic [Photo2].

The creation of The Road to Happiness [in Polish Droga ku Szczęściu], connecting the village of Graniczna situated in the upper part of the Podgórna Valley, integrated into Duszniki in 1840, with the Golden Drift [in Polish Ztota Sztolnia], the peak of Orlica and Zieleniec, also intensified hiking in this region. The Golden Drift, the largest marble cave in Silesia and discovered in the $17^{\text {th }}$ century, became an attractive place in the vicinity of which the Mensehorst am Goldenen Stollen youth hostel was built in 1927 on the Orlicka Road, then extended by a second building in 1936 [Photo 3].

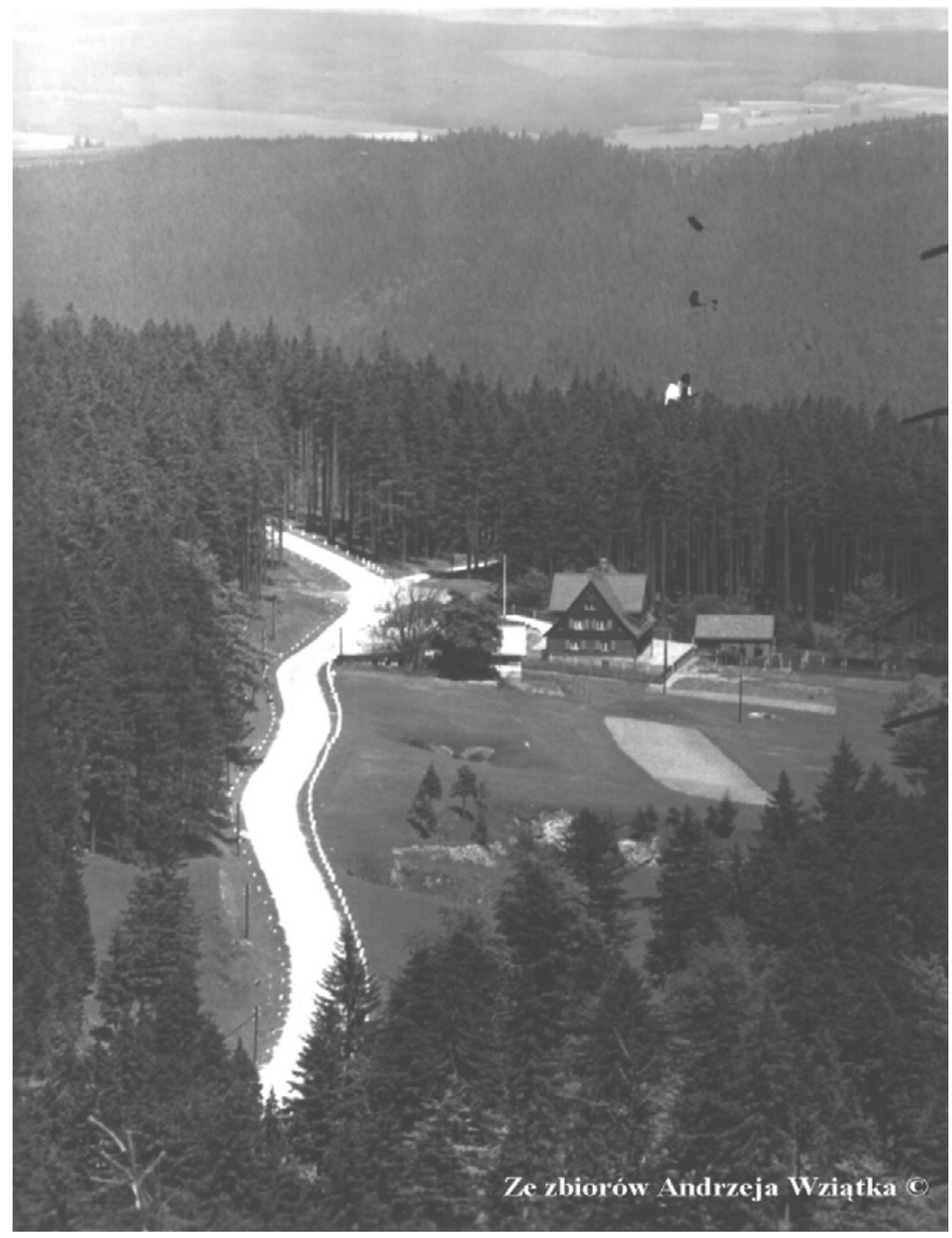

Fig. 3. The Mense Horst am Goldenen Stollen hostel after its extension in 1936. Located by the Orlicka road*. Source: from Andrzej Wziątek's collection.

Schronisko Mense Horst am Goldenen Stollen po rozbudowie w 1936 roku. Położone przy drodze Orlickiej**. Źródło: ze zbioru Andrzeja Wziątka.

* The complex of buildings forming this hostel was unfortunately devastated and destroyed after 1945

** Zespół budynków tworzących to schronisko został niestety zdewastowany i zniszczony po 1945 roku.

At the end of the 1880s, Rübartsch intended to renovate the tower, but the GGV authorities, with a jealous eye on the growing popularity of the hostel at the top of Orlica, tried to hamper the development of the activity as well as possible and did not want to participate in the renovation work. Prince Coloredo Mansfeld, the owner of the Austro-Hungarian border areas, helped Rübartsch, as he agreed to build a new tower on his imperial side of the border. His acquaintance with the prince brought another benefit to Rübartsch, namely the skis the aristocrat brought with him from one of his journeys to Norway at the end of the 1980s. So the lord of Orlica, as Rübartsch was also called, was the first to leave traces of skiing in the snow there. The old hostel 
was also replaced at the beginning of the $20^{\text {th }}$ century, with a new one with a cellar and attic and 20 beds. The owner himself moved in 1904 to his hostel on top of Orlica, leaving the inn in Zieleniec for his family. The inn building survived until the 1960s, when it was demolished. The hostel on Orlica (Gasthaus auf der Hohen Mense) was open all year round and the most attendance was in summer (18). Zieleniec grew without losing its original character of a mountain settlement with scattered wooden buildings. At the beginning of the twentieth century it was inhabited by almost 900 people, there was a stone Neo-Romanesque church, there were prepared ski trails, a toboggan run and a small ski jump with a wooden structure near the church. Accommodation services also expanded and in addition to the hostel at the top of Orlica, there were the following facilities there: Grunwaldbaude, Kastnersgasthaus, and Gasthaus zur Mense, run by the Rübartsch family.

Unfortunately, the time of economic prosperity, including the expansion of the network of hostels, inns, guesthouses and villas in the Sudetes was interrupted by the outbreak of the First World War. Also the whole Kłodzko Land was affected by changes. The creation of Czechoslovakia in 1918 changed the character of the border between the newly born republic and the German state. So also Rübartsch had to remove his tower from the Czech side - and build a new one on the German side.

\section{Interwar period}

In the 1920s, several new mountain hostels and inns were built near the Orlica summit in competition with the Rúbartsch's inn. The first of these was the Masarykova Chata hostel built in 1925 under the peak of Šerlich on the Czechoslovakian side. The author of the winning design, selected through a competition, was Boguslav Fuchs, a well-known Czech architect [Photo 4]. The hostel had the then fashionable, stepped roof form, covered initially with shingles, later with sheet metal. The walls were secured with tiles laid in a diamond pattern. The roof definitely dominated the whole building shape, giving it a compact character. On the ground floor there was a hall, entrance area, a restaurant with a verandah and a kitchen, rooms for employees and a small dining room accessible from the main corridor, and a hygienic and sanitary part. There was also a farm zone with rooms for pigs, goats and cows with a manure pit and woodshed. These rooms were accessible from the inner courtyard or from the main hall. For winter there was a ski room (for skiers and equipment) on the ground floor, accessible from the outside. On the first floor there were bedrooms and washing facilities [Photo 5].

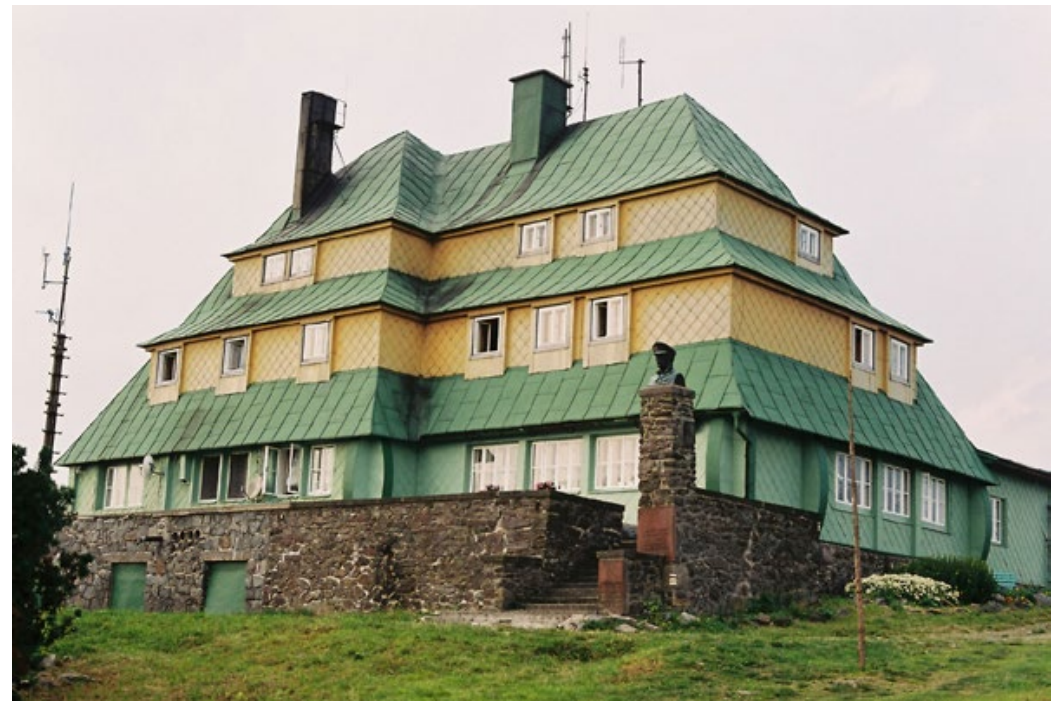

Fig. 4. The Masarykova Chata hostel on the slope of Šerlich, near the border with Poland. This facility was built in 1925 . Photo by the author. Condition as of 2009.

Schronisko Masarykova Chata na stoku Śerlicha, przy granicy z Polską. Obiekt ten powstał w 1925 roku. Fot. autor. Stan 2009.

In June 1928, a new hostel, Hindenburgbaude, was opened in the Orlica massif in Zieleniec, inspired by the regional architecture of the Kłodzko Land. The author of the design was Konrad Goebel, an architect of the city of Kłodzko and vice-chairman of the ZG GGV. In the entrance area in the main hall, there was a cloakroom and a room for keeping skis, and closer to the main staircase - washing facilities. Then you could go to one of the 
four guest rooms; two larger rooms and two smaller ones, one of which was protruding in the form of a verandah to the northwest direction, with a stone structure. The plan was complemented by rooms and kitchen for the hostel manager and (garage) storage rooms accessible from the inner courtyard. On the first floor there were group bedrooms planned, as thirteen- and eight-bed rooms and four single rooms with washing facilities. Accommodation was provided in the attic as well [Photo 6]. The building had a wooden structure based on a stone base course. The whole building shape was crowned with a steep gable roof covered with shingles. The cosy interiors with regional decoration also deserved attention. Next to the hostel there were petrol pumps for cars which, as in the case of Masarykova Chata, could get there.
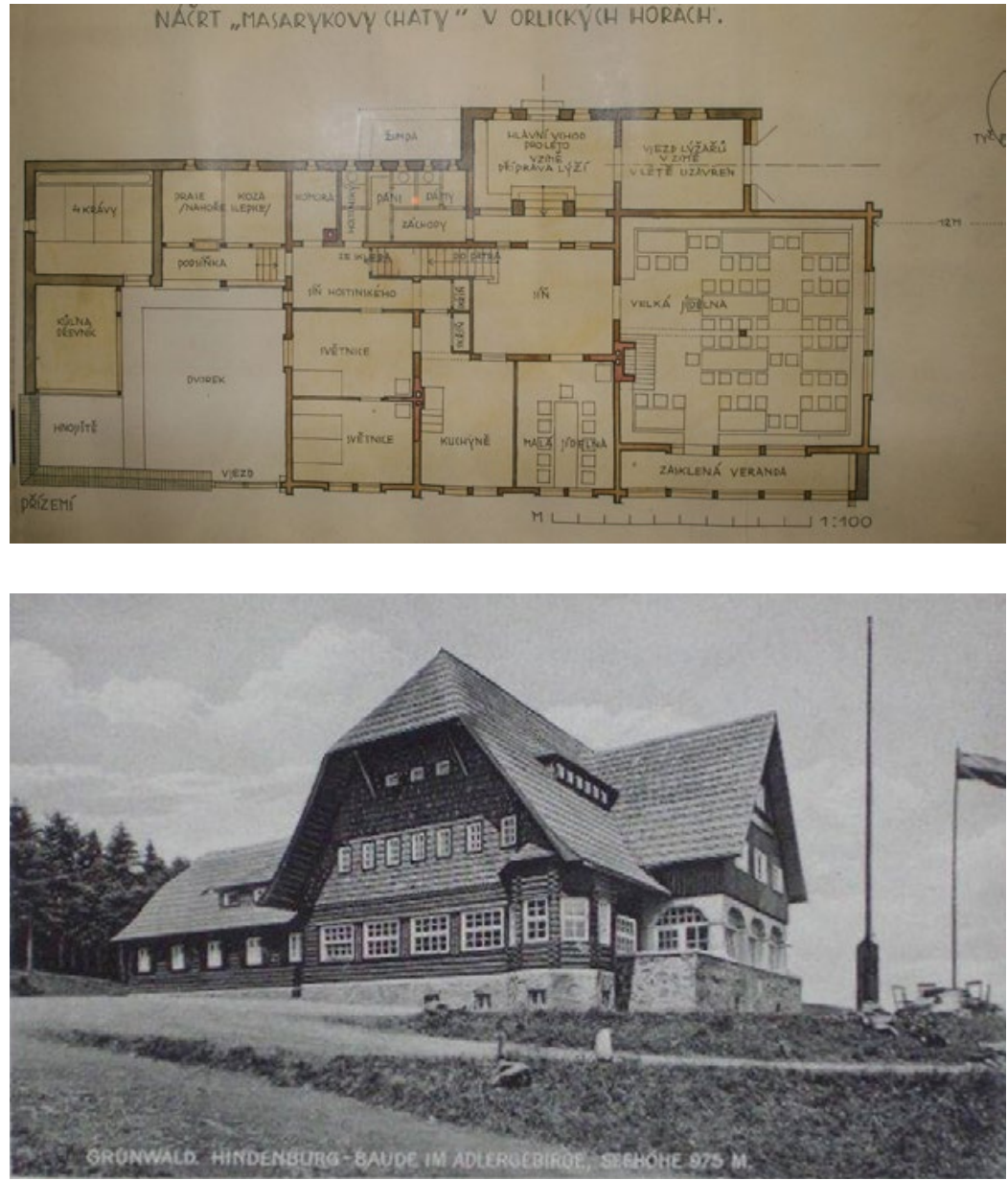

Fig. 5. The ground floor plan of Masarykova Chata at the post-competition exhibition in Orlické Záhoři in 2010. Photo by the author.

Rzut parteru schroniska Masarykova Chata na wystawie pokonkursowej w Orlickich Zahorach w 2010 roku. Fot. autor

Fig. 6. The non-existent Hindenburgbaude hostel established in 1928 in Zieleniec, at the foot of Orlica at an altitude of $975 \mathrm{~m}$ above sea level* Source: www.wroclaw. hydral.com.pl

Nieistniejące schronisko Hindenburgbaude powstałe w 1928 roku w Zieleńcu, u podnóża Orlicy na wys. 975 m n.p.m**. Źródło: www. wroclaw.hydral.com.pl

* This facility was one of the most successful in terms of its form inspired by regional threads, well-thought-out function and selected architectural detail. Currently, this place is overgrown by a forest which is several dozen years old.

** Obiekt ten należał do szczególnie udanych pod względem inspirowanej wątkami regionalnymi formy, przemyślanej funkcji i dobranego detalu architektonicznego. Obecnie to miejsce porasta paro-dziesięcioletni las.

Both hostels were only 20-30 minutes away from each other and were built in a short time, separated by the state border. Their fate was also different. The Czech hostel still exists today, despite the turmoil of war, and the German hostel considered beautiful with a regional, balanced form unfortunately burned down completely in November 1948, after it was left by the WOP (Border Guard Troops) establishment.

The construction of an eight-kilometre-long Hindenburg road (Hindenburgstraße) in 1931-32, now known as the Orlice Road, leading from the Polskie Wrota pass through Zieleniec to the crossroads with the Dusznicka Road under Hutnicza Kopa, was of fundamental importance for the development of Zieleniec and the nearby villages. Marshal Paul von Hindenburg covered part of the construction costs. In addition to the above mentioned hostels in Zieleniec, there were a few more until 1945. These were: Reinerzer Skihűtte Grunwald, Ritterbaude and 
Adlerbaude in the central part of Zieleniec. The Kammbaude Grunwaldkrone hostel was located at the highest altitude and a little lower was Berghof Rúbartsch [Photo 7]. The Kastnera i Hanka inn was located in the central part of the village. In total, there were more than 250 beds at the disposal of tourists in the rooms of hostels and inns, plus about 90 in collective rooms and more than 25 in private accommodation. The vast majority of the facilities listed here showed a regional character in their form and detail, characterized by scattered buildings, in this beautiful mountain landscape. The topography was also used more and more intensively for sports purposes in Zieleniec. In addition to the ski areas and ski school, there were four toboggan runs, one of which was more than $2 \mathrm{~km}$ long under Hindenburgbaude, there were also two skating tracks, an ice rink for hockey, and a wooden ski jump near the church, for jumps up to $40 \mathrm{~m}$ long. In 1930 Heinrich Rübartsch, co-author of the development of Zieleniec as a popular winter sports center and a village with significant tourist values, also in summer due to a well-developed network of hiking trails connecting with the Czech Republic on the other side of the border, passed away. In the panorama of the locations on and near the Dzika Orlica river, it was also possible to distinguish buildings erected in the 1930s of border guards and customs offices, with the form and proportions inspired by the local regional architecture. Near Zieleniec, in the developments of the Mensehorst am goldenen Stollen hostel such a building appeared in 1936, and in the village itself, one building of this kind was located in its center, and three other at the end of Zieleniec, which are now called Forest Apartments and act as guesthouses. They are characterized by a high, steep, gable roof, solid stone base course, brick walls of the ground floor, covered with boards from the outside, as well as a vertically boarded gable wall [Photo 12]. In the attic there was often a large dormer window which indicated the existence of living quarters.

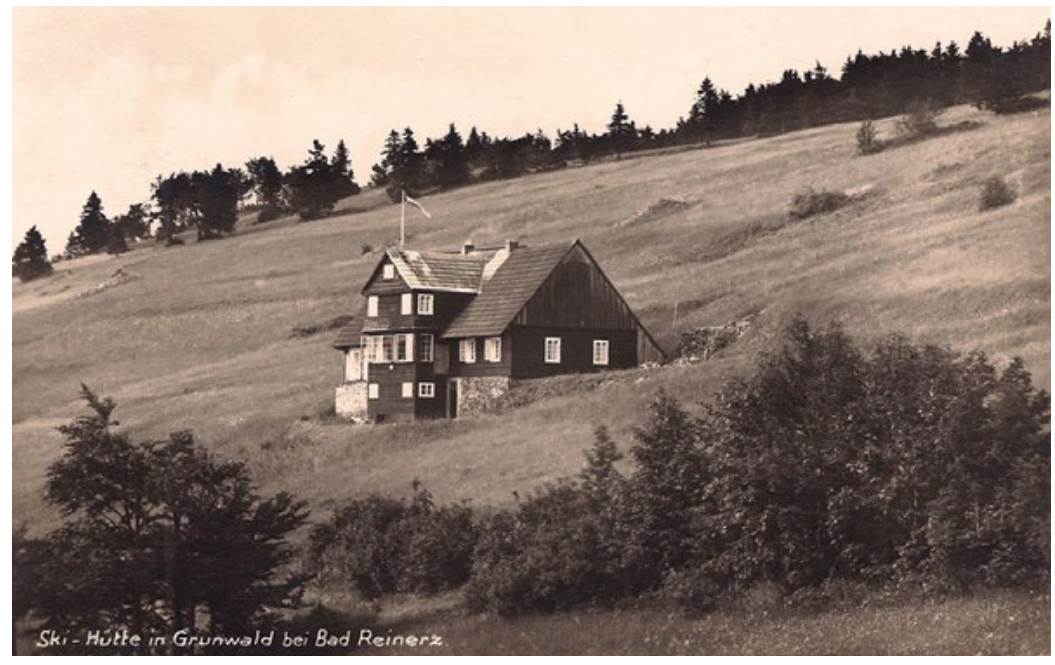

Fig. 7. A non-existent hostel-guesthouse in Zieleniec (most probably Berghof Rübartsch). Interwar period. Source: www.wroclaw.hydral.com.pl Nieistniejące schronisko-pensjonat w Zieleńcu (najprawdopodobniej Berghof Rübartsch). Lata międzywojenne. Źródło; www.wroclaw. hydral.com.pl

\section{After 1945}

After 1945, most of the pre-war shelters operated in Zieleniec, except for Hohe Mense Baude at the top of Orlica and Hindenburgbaude, burned down in 1948, which could certainly include, next to Samotnia (Kleine Teich Baude) on Mały Staw in the Giant Mountains and Lucyna (Múller Max-Baude) in the Sowie Mountains to most fittingly referring in their form to the rich heritage of regional architecture in the Sudetes (15).

Unfortunately, in the fifties and sixties of the $20^{\text {th }}$ century many of the existing hostels and inns in Zieleniec were demolished, such as Kammbaude Grunwald Krone called after the war - Crown, Adlerbaude bearing the Polish name Janosikowa Hala and in 1967 Ritterbaude named Orlica III, or Berghof Rübartsch. The youth hostel Mensehorst am goldenen Stollen also ceased to exist. On the other hand, new buildings were built after 1945, as for example in the second half of the 1950s, the building of the Warsaw University of Physical Education in the center of Zieleniec. In the 70 s of the $20^{\text {th }}$ century ski lifts were built and some pre-war buildings were rebuilt. The status of a hostel named Orlica was granted to a pre-war inn built in 1878. After the Second World War in the 1950s, there was a tourist station of the Institute of the Polish Academy of Sciences, and since 1960 

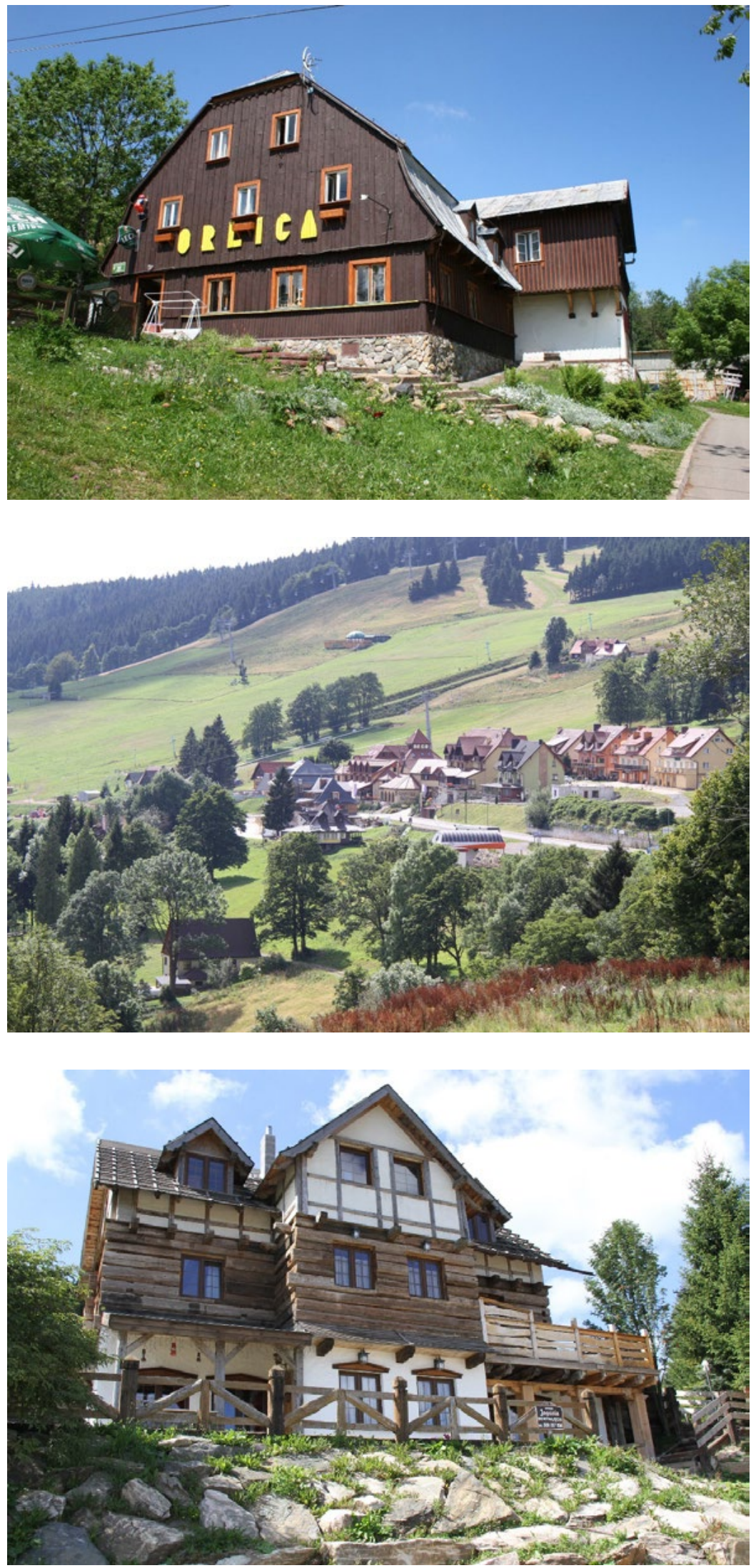

Fig. 8. The Orlica hostel, currently the oldest building in Zieleniec, erected in 1878 (recently unveiled inscription on the board under the nosing on the gable wall). The former inn since the $60 \mathrm{~s}$ of the $20^{\text {th }}$ century serving as a hostel. Photo by the author -2009 .

Schronisko Orlica, obecnie najstarszy budynek w Zieleńcu, wzniesiony w 1878 roku (niedawno odsłonięty napis na desce pod naczółkiem na ścianie szczytowej). Dawny zajazd od lat 60-tych XX wieku pełniący rolę schroniska. Fot. autor, 2009.

Fig. 9. Guesthouse development in Zieleniec (Szarotka complex) built in the last couple of years distorts the character of the old, free location of buildings, currently creating a compact complex with uninteresting architecture. Photo by the author $-2017$.

Powstała w ciągu ostatnich paręnastu lat zabudowa pensjonatowa w Zieleńcu (zespół Szarotka) wypacza charakter dawnej, swobodnej lokalizacji obiektów, tworząc obecnie zwarty kompleks o nieciekawej architekturze. Fot. autor 2017.

Fig. 10. A recently constructed guesthouse in Zieleniec with quite surprising structural and formal solutions of external walls. The transom system of attic beams contrasts with the wooden and log load-bearing system of the first floor (recycled building material), and brick walls (?) of the ground floor. Photo by the author - 2017 .

Niedawno powstały w Zieleńcu pensjonat o dość zaskakujących rozwiązaniach konstrukcyjno-formalnych ścian zewnętrznych. Ryglowy układ belek poddasza kontrastuje z drewnianym-zrębowym systemem nośnym piętra (budulec z odzysku), oraz murowanymi ścianami (?) parteru. Fot. autor, 2017 
there has been a hostel of the Polish Tourist and Sightseeing Society (PTTK) Orlica [Photo 8]. Also after some time two buildings were adapted for the needs of the hostel, thus increasing the number of beds. The building itself in its form and detail is an example of one of the varieties of regional construction in the Kłodzko Land. Steep gambrel roof with a nosing, brick and wooden superstructure with decorative elements of roof rafters, proportions of ground floor walls and roof, vertical boarding of the gable wall and the ground floor do not leave any doubts as to the regional origin of the building (15).

Unfortunately, the appearance of new tourist buildings in Zieleniec in connection with its development after 2000, differs fundamentally in form, the building material used, and the lack of architectural detail, from former regional buildings. The shortage of suitable land for new structures prompted investors to cut down trees and choose land from the slope of Šerlich in the place where the tourist complex Szarotka is currently located [Photo 9].

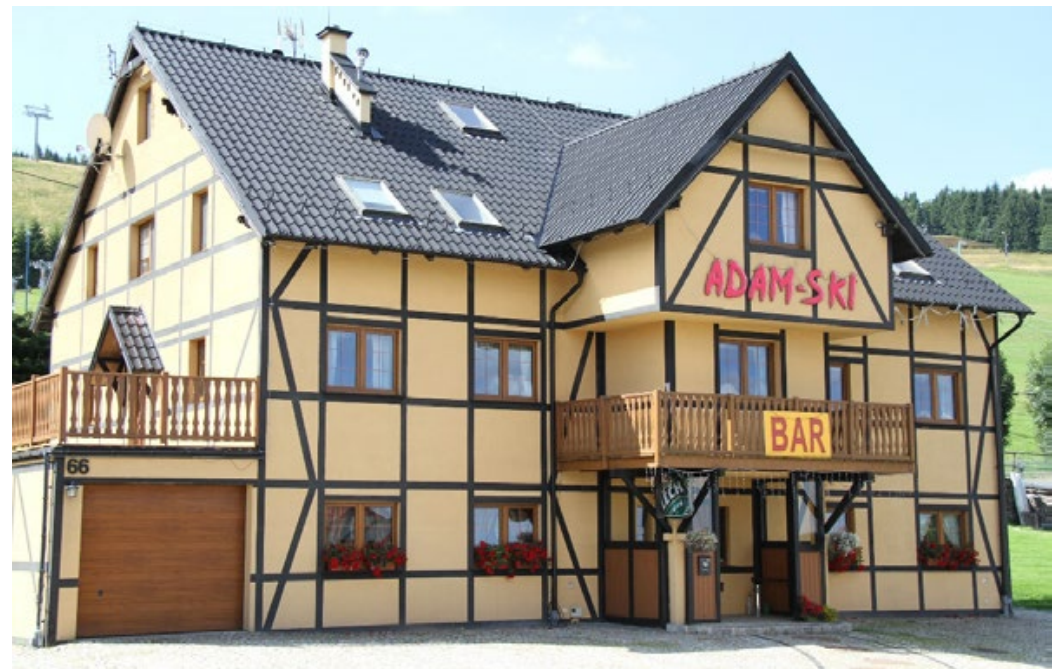

an

Fig. 11. An unprofessionally designed arrangement of transom structure elements on the walls of the ground floor and the first floor of the hotel building in Zieleniec, designed to suggest a real structure, gives the impression of artificiality and randomness to an outside observer.

Niefachowo zaprojektowany układ elementów konstrukcji ryglowej na ścianach parteru i piętra budynku hotelu w Zieleńcu, mający sugerowac prawdziwą konstrukcję, powoduje wrażenie sztuczności i przypadkowości u postronnego obserwatora**. Fot. autor 2017.

* Photo by the author - 2017. This problem is discussed in Manferd Gerner's book entitled "Fachwerksünden" published by Deutsches Nationalkomitee für Denkmalschutz Band 27, Bühl/Boden, 1989.

** Problem ten omawia w swej książce Manferd Gerner pt. „Fachwerksűnden” wydanej przez Deutsches Nationalkomitee für Denkmalschutz Band 27, Bühl/Boden, 1989

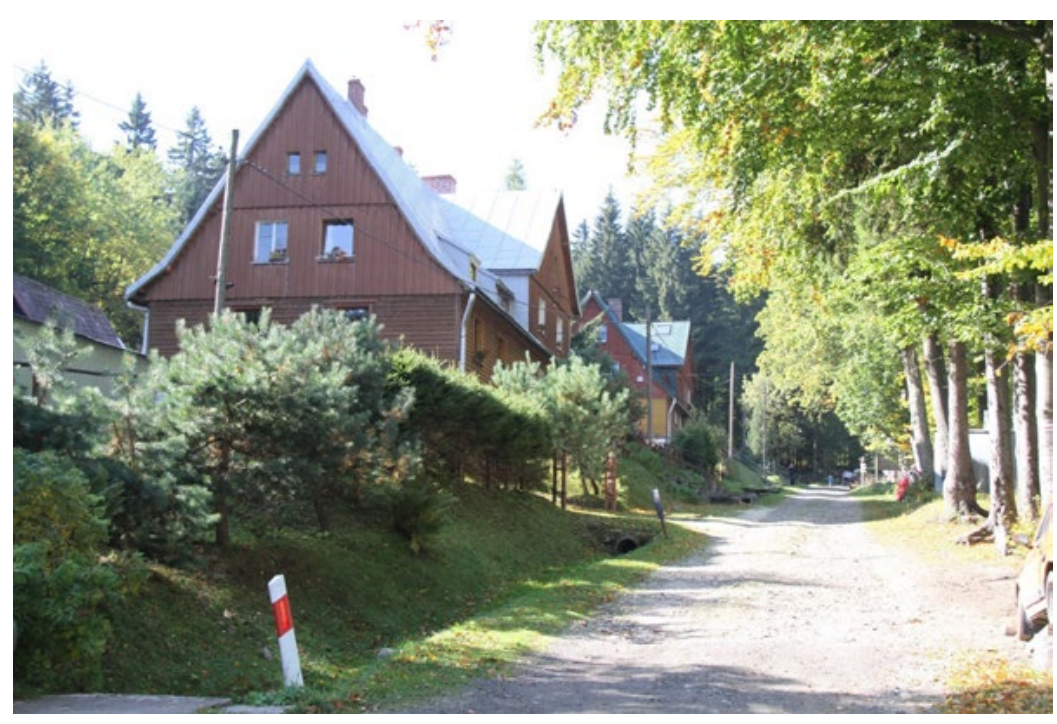

Fig. 12. Zieleniec. Leśne Apartamenty, former border guard buildings from the 1930s, now adapted to the leisure function. Photo by the author - 2017.

Zieleniec. Leśne Apartamenty, dawne budynki strazy granicznej z lat 30-tych XX wieku, obecnie przystosowane do funkcji wypoczynkowej. Fot. autor 2017. 
In Zieleniec there are developments with a compact, expanding form, unusual for the landscape of this mountain village. This controversial phenomenon is undoubtedly complemented by the increasing number of ski lifts and cable cars, as well as storage rooms located by the main road for equipment used for the preparation of slopes and other equipment in winter. The recently built third platform for the free passage of skiers over the main road interferes with the view of the spreading out buildings.

As a result of the chaos, Zieleniec has been growing rapidly in recent years, on the other hand, providing new jobs for the inhabitants of the surrounding villages. However, many questions arise about the disappearing architectural distinctiveness of this village, which unfortunately becomes one of many places of this type marked mainly by the spirit of commerce, which results in the construction of buildings with an uninteresting, even boring form [Photo 10,11]. A certain chance to avoid mistakes made in the rapid development of Zieleniec is the example of the neighboring Lasówka, a village of a different type of development, freely scattered in the area with much smaller slopes, adapted in winter more for cross-country skiing.

\section{Lasówka and glassworks}

The history of this picturesquely situated village in the Bystrzyckie Mountains in the Dzika Orlica valley, on the slope of Kłobuka are inseparably connected with glassmaking. As early as in 1614 in the neighbouring Czech Bedřichovka (Friedrichsdorf) Hans Friedrich, the founder of the glassworks in Szklarska Poręba and Jugów, opened a glassworks there too, which was destroyed during the Thirty Years' War. Probably in the area of today's Lasówka there was already a settlement of glaziers (some sources report the end of the $16^{\text {th }}$ century) which, as well as other locations on the Dzika Orlica river on its right and left side, was depopulated and brought down.

After the end of the Thirty Years' War in 1656, a Czech glass-making master from Bedrichovka, Adam Peterhansel, founded a glassworks in the imperial forests and after obtaining the right to locate settlements and glassworks in the valley of the Dzika Orlica river he founded Lasówka on 29 July 1662 . The name of this settlement - Kaiserswalde (Eng. imperial forest) refers to its origin $(1,8,18)$. Lasówka developed well and in 1693, i.e. when its founder died, the glassworks belonged to the larger and more significant in the region.

A document from 1743 has survived, according to which there were 13 cottagers, 2 well-to-do peasants, 8 villeins, 1 blacksmith, 1 miller, 1 innkeeper and 3 glaziers living in Lasówka. There were 3 cows and 3 goats in the estate. The subjects had 13 cows and 3 goats. Apart from the glassworks there was a manor farm and a water mill. In the following years Lasówka and the glassworks changed owners, until 1801 the whole of it passed into the hands of Johan Christof Rohrbach who in 1812 thoroughly rebuilt it. There were 42 buildings, a water mill and a lime kiln in the village at that time. The glassworks employed 14 people.

From 1853 the glassworks and Lasówka were taken over by the von Pangratz family who owned it until 1945 apart from the short episode of 1854-55 $(1,11,18)$.

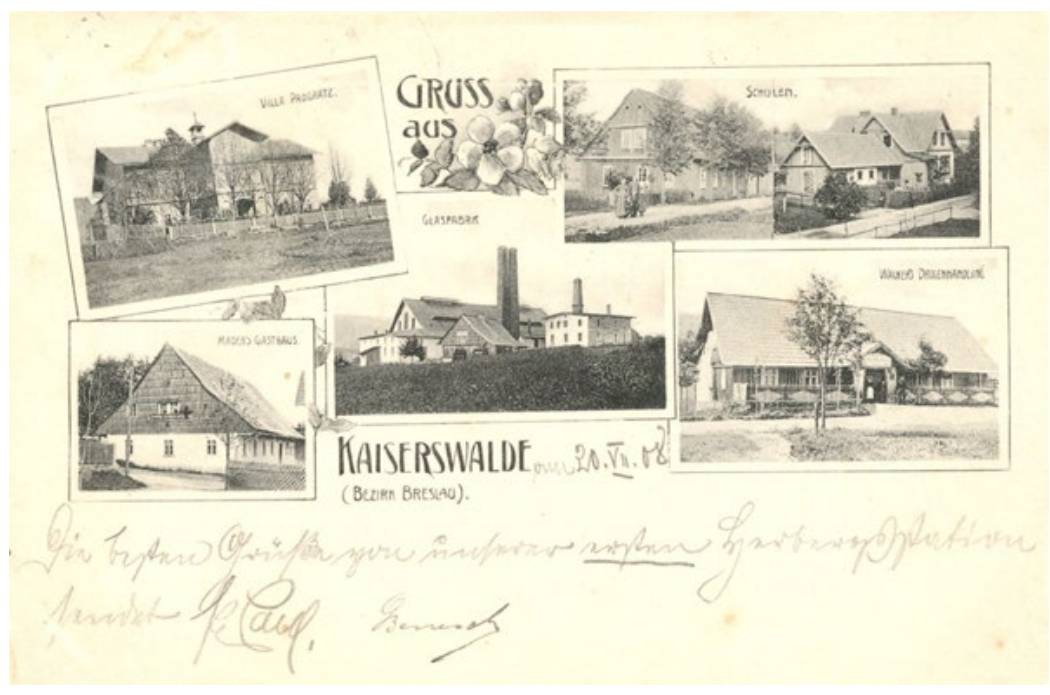

Fig. 13. A five-field postcard from 1908, depicting the glassworks, Villa Pangratz, Madera inn, school building and drugstore in Lasówka. Source: from the collection of the Museum in Wałbrzych.

Pięciopolowa pocztówka z 1908 roku, przedstawiająca: hutę, Villę Pangratz, zajazd Madera, budynek szkoły i sklep drogeryjny w Lasówce. Źródło: ze zbioru Muzeum w Wałbrzychu. 
From the very beginning Lasówka was associated with the establishment of a glassworks and not with agricultural production, which was largely due to its location in mountainous terrain at an altitude of 680-730 m above sea level, soils of low quality, short vegetation period and low average temperature and extensive spruce and beech forest areas. Only successful was cattle breeding on the vast meadows surrounding the village. On the other hand, the unprofitability of agricultural production, cultivation of cereals, potatoes, fruit trees and vegetables, nature made up for the founders of the glassworks with crystal clear streams, countless forest resources, deposits of quartz sands and the border location with the Czech Republic, which was of great importance for the development of the glass industry because it enabled close cooperation. People living there found employment outside the glassworks as painters, engravers and, above all, grinders who in their small wooden houses processed the glass supplied from the glassworks. Others worked as woodcutters in forests, in wood transportation, sand transport, forest ground cover harvesting, or in their workshops they dealt with cottage weaving [Photo 13, 14].

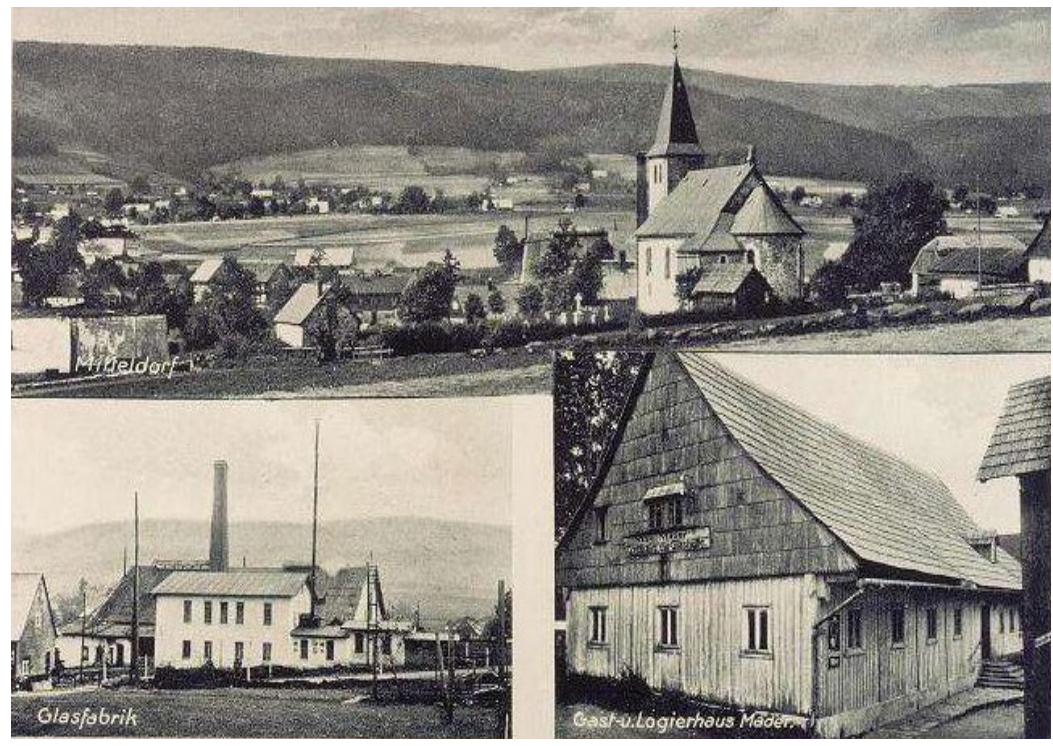

Fig. 14. Lasówka before the First World War. A three-field postcard with the glassworks, Madera inn and a panorama of the village with a church. Source: own collection.

Lasówka przed I wojną swiatową. Pocztówka trójpolowa na której znajdują się: huta szkła, zajazd Madera oraz panorama wsi z kościołem. Źrodło; Zbiory własne

In the center of Lasówka there was also a manor farm with a noble seat (1753). It was located south of the glassworks by a rural road (1).

When King Frederick II of Prussia as a result of victorious wars took over Silesia, including the county of Kłodzko, an order was issued to ban the import of glass, mainly from the Czech Republic to protect and strengthen domestic glass industry. Despite the existence of two glass production centers in the Kłodzko Land, the largest one with glassworks in Strachocin, Wilkanów, Szklarka, Szklarnia, Różanka, Długopole Górne, Poniatowo, Piaskowice, Lasówka and Spalona and the second one with glassworks in Jugów and Woliborz, the glass production was insufficient $(1,18)$. Frederick II decided to set up a new large glassworks in Batorów (Friedrichsgrund) near Szczytna, and entrusted the task of construction to Ignatz Rohrbach, a representative of a well-known family of glaziers who was a leaseholder of the glassworks in Lasówka from 1768. The glassworks in Batorów produced colored, engraved and gold-plated crystal glass. In the first half of the $19^{\text {th }}$ century, next to the glassworks "Józefina: in Szklarska Poręba was the largest in Silesia, and its products were popular on the European markets.

After the death of Ignatz Rohrbach in 1792 the plant in Lasówka was taken over by his brother Christof. After the reconstruction of the glassworks in 1812, eight years later it employed 34 men and 3 women, and in the grinding shop 5 men and 2 women worked. Unfortunately, in 1894 the old glassworks was destroyed by fire, but during the year a new plant was erected (18) [Photo 15].

The first grinding shop was located in Lasówka above the manor house, but then it was moved to replace the former drawn glass factory and had a steam drive. Apart from the glassworks, the inhabitants of the areas above the upper Orlica were also employed in the match factory. At the end of the 1830s, the match industry started to develop well in this region. In 1845 Ferdinand Wenzel from Poręba founded a match factory in Lasówka 
which already in 1869 employed 19 men and 22 women. The plant grew and offered work to homeworkers who produced matches covered with white phosphorus. Also the production of wooden boxes for matches was developed in Lasówka, which created new jobs, especially in winter. After some time, the production of matches packaging was replaced by packaging for the medical industry. Other packagings for shoe cleaning utensils, greases and fats, as well as night lighting were also produced.

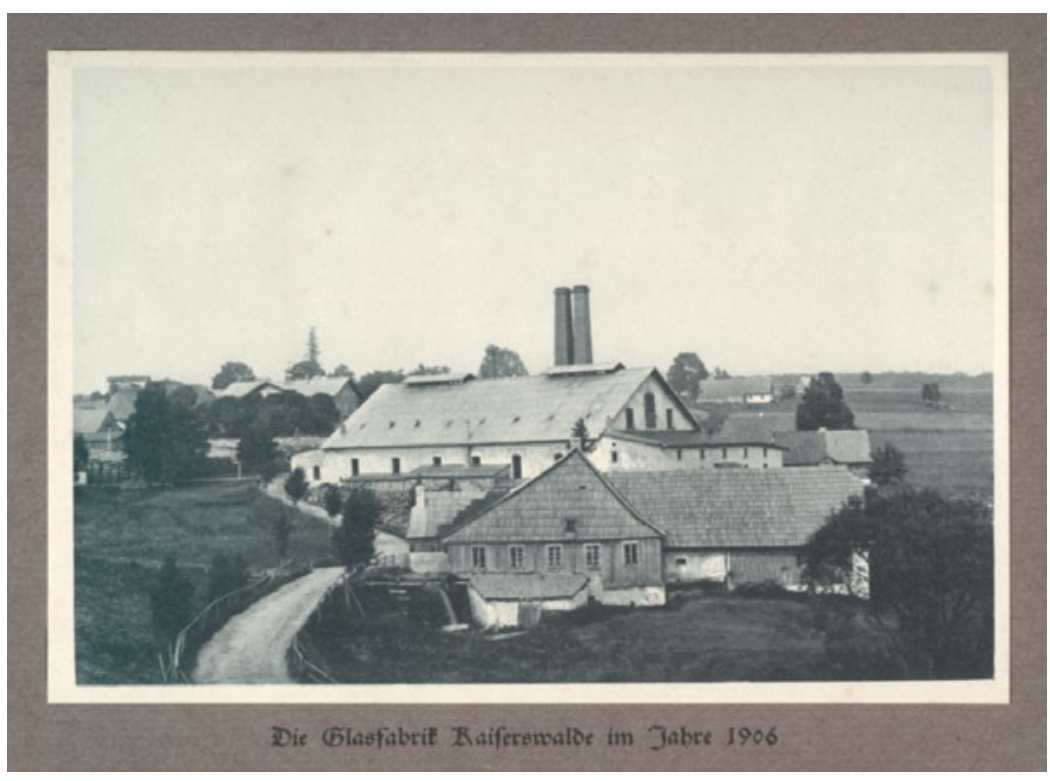

Fig. 15. Lasówka. The glassworks in 1906. The building was closed and demolished at the beginning of the 1950s. From the collection of the Museum of the Kłodzko Land.

Lasówka. Huta szkła w 1906 roku. Obiekt ten został zamknięty i rozebrany z początkiem lat 50-tych XX stulecia. Ze zbiorów Muzeum Ziemi Kłodzkiej.

In the neighbouring village of Piaskowice (Friedrichsgrund) owned by Lasówka, the brothers Ludwig and Oskar Holup founded an artificial jewelery factory (Simili - Edelsteinfabrik) on the site of a paper factory in 1906. The working conditions in the new factory were better than those of the matchmakers in their small, narrow and lightless homes $(1,18)$.

Due to the mountainous location of Lasówka, the problem was the access to school for children living there, especially in winter. Since 1780 it was located in Mostowice, a few kilometres away. Children from wealthier families lived in Mostowice at their friends' during the winter or attended school in the Czech Republic in the neighboring village of Friedrichswald.

It was not until 1850 that the so-called winter school was opened in Lasówka in an adapted room, which operated from October to the end of April. This state of affairs lasted for 13 years, when it was possible to purchase land for the construction of a new school with state funds. The official opening of the school in Lasówka took place on 14 October 1864 and the number of students was 65.

The growing number of pupils ( 116 at the turn of the $20^{\text {th }}$ and $21^{\text {st }}$ century) made it necessary to build a larger school with three classes and apartments for teachers. Thus, at the turn of 1898/99 a new building was put into use, where there was also an apartment for a second teacher.

The construction plan of a church in Lasówka, drawn up as early as 1780 , was under implementation only at the beginning of the $20^{\text {th }}$ century. The industrialization of the village entailed an increase in the number of inhabitants, and so in 1789 it amounted to 188 people, in 1804 there were already 290 people living there, and the census of 1 December 1910 confirmed the number of 659 inhabitants, 650 of whom were Catholics.

The church construction plan was prepared by Paul Blau, a bricklayer and carpenter from Lewin, already experienced in the construction of this type of buildings as he was the author of the churches in Zieleniec and Kudowa. A plot of land in the village opposite the glassworks and manor farm has been designated for the location.

The Church of St. Anthony belonging to the parish of Mostowice, with clear influences of Romanesque style in its form, was designed as a single-nave church, oriented with a 30-metre tower from the west on a square plan. The foundation stone was laid on 25 May 1911 during Ascension Day.

The solemn consecration of the church took place on 17 September 1912 and the temple and the community were placed under the care of St. Anthony (8). 


\section{Interwar period}

In the interwar period, the Lasówka crystal glass factory (Kristall -Hüttenwerke Pangratz \& Co Kaiserswalde, Krs. Habelschwerdt) continued to operate in Lasówka, producing new varieties of crystal glass, introducing to the European and North American markets a wide range of utility glass designs, which was very popular among numerous customers. The plant was modernized and expanded, among other things, electric heating of glass melting furnaces was installed and semi-automatic devices for the production of glass panes were purchased. The number of grinding and engraving workshops increased and the employment reached 85 people $(1,8)$.

The glassworks and grinding plant in Lasówka became a part of an industrial cartel together with plants from Szczytna, Batorów, Duszniki-Zdrój, Polanica-Zdrój and Stronie Śląskie. The woodworking industry developed and boxes for the pharmaceutical and match industries were produced (18).

In 1936 Lasówka had 750 inhabitants, most of whom were employed in the traditional branches of manufacturing in the region. A certain, small part of it found its place in services related to tourism and recreation. Already before the First World War Lasówka was classified as a summer resort $(3,4,7,14)$.

According to guides from the interwar period, there were two inns in the village offering accommodation and food for tourists. The first one is an inn located near the church - Max Maders Gasthaus "Zur Glashütte". It had 7 rooms with 14 beds. It also had a restaurant and a youth and student hostel.
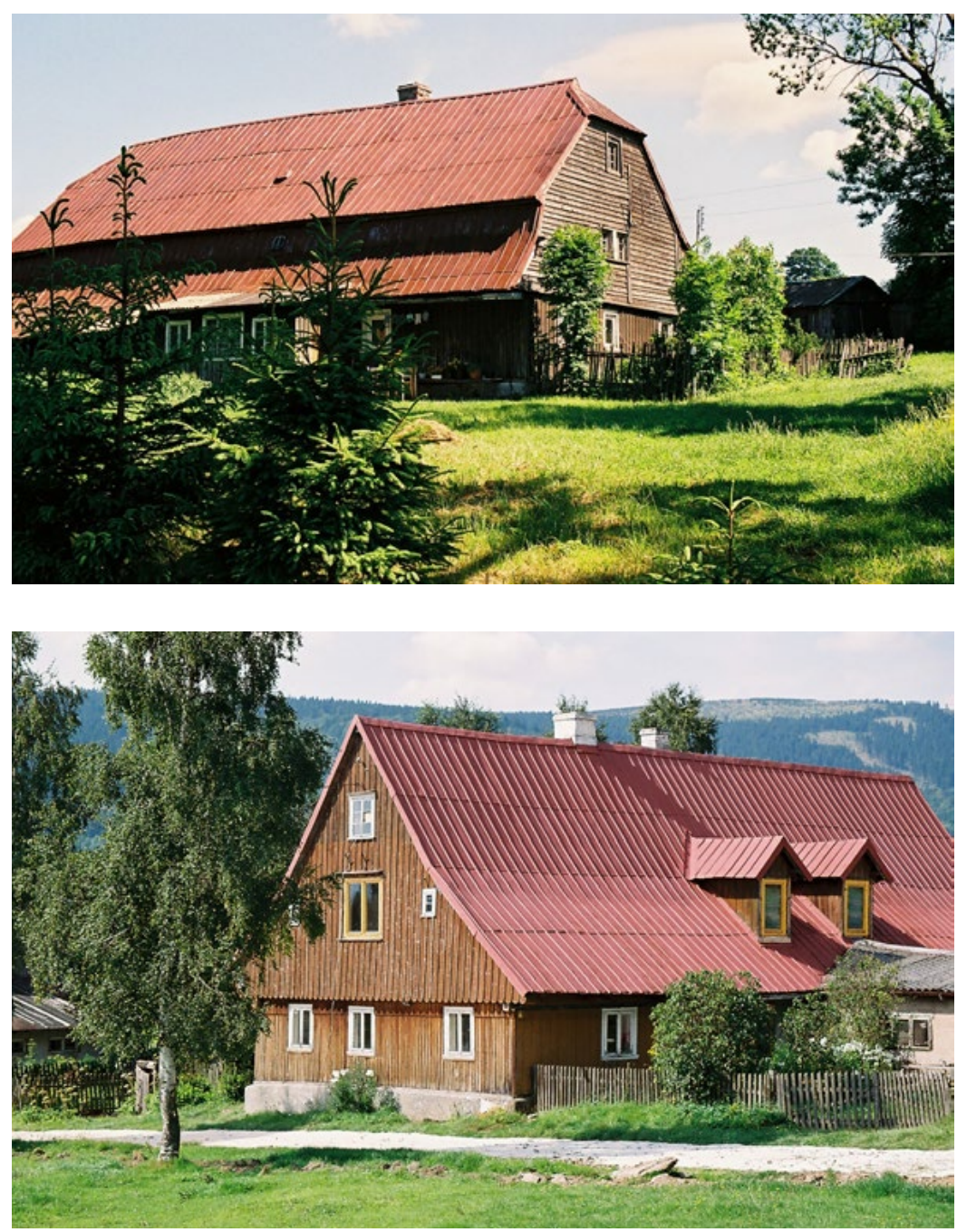

* Initially in the twenties of the twentieth century, there was an inn - Stumpfgasthaus.

** Początkowo w latach dwudziestych XX wieku, istniała tu gospoda Stumpfgasthaus.
Fig. 16. Lasówka. Residential building was built before 1945 with distinct regional features in proportion and architectural detail. Photo by the author - 2016 .

Lasówka. Budynek mieszkalny powstały przed 1945 rokiem o wyraźnych cechach regionalnych w proporcji całości i w detalu architektonicznym. Fot. autor. 2016.

Fig. 17. Lasówka. The former Erlitztalbaude hostel* near Mostowy Potok. Visible regional features of the building's architecture. Currently a private property. Photo by the author - 2005 .

Lasówka. Dawne schronisko Erlitztalbaude ${ }^{* \star}$ w pobliżu Mostowego Potoku. Widoczne regionalne cechy architektury budynku. Obecnie obiekt prywatny. Fot. autor. 2005. 


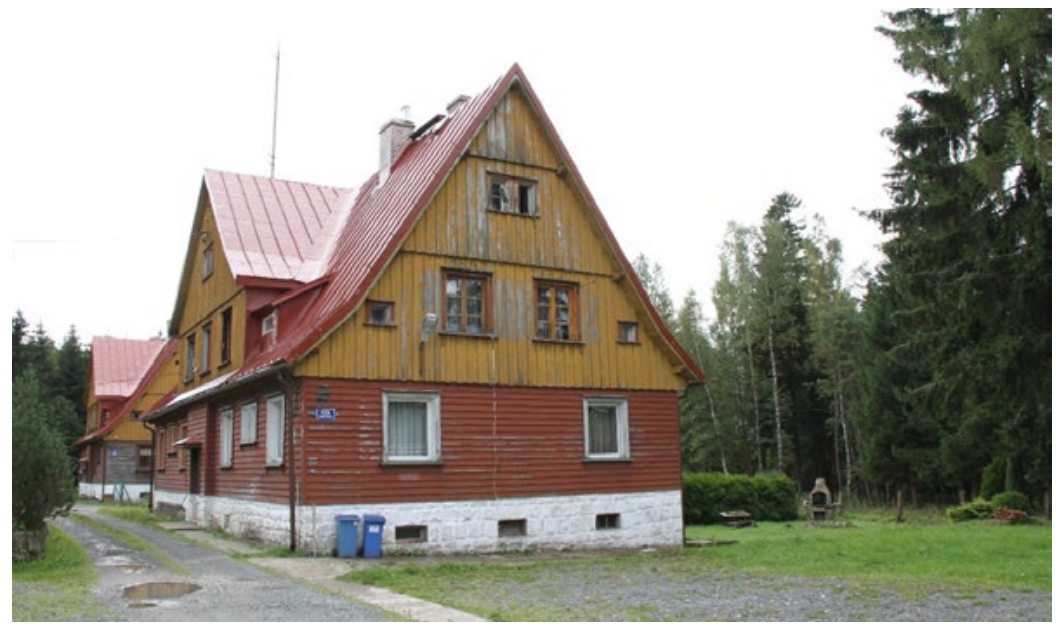

Fig. 18. Border guard buildings erected in 1938 in Lasówka. The proportions of the whole and architectural detail indicate the regional character of the objects. Photo by the author. 2017.

Budynki straży granicznej wznisione w 1938 roku w Lasówce. Proporcje całości i detal architektoniczny wskazują na regionalny charakter obiektów. Fot. autor. 2017.

The second one is "Stumpf Gasthaus" with 3 rooms and 7 beds located in the north-western part of Lasówka over Mostowy Potok [Photo16]. The inn, which already had 9 beds at the end of the 1930s, changed its name to "Erlitztalbaude", meaning a hostel in the Orlica valley (15). In the area of the Royal Forest colony near the forester's lodge, there was also a small hunting hostel "Sandbaude". Its post-war fate is not known. In the summer, from the train station in Bystrzyca Kłodzka there were 3 buses (das Postauto) to Lasówka, which made it possible for tourists to get to this region of the Bystrzyckie and Orlickie Mountains fairly conveniently, as well as to pass to the Czech side of Orlica. In winter, postal bus routes reached only Wójtowice-Młotów (Voigsdorf - Hammer), i.e. the villages located lower than Lasówka.

Despite its peripheral location, Lasówka had a postal agency with a call office located near the Max Madera's inn. There was also a final stop of postal buses $(10,18)$. With its buildings Lasówka connected with Bedriichovka (Friedrichswald), Třckov (Trtschkadorf) and Zelenka (Grünborn), on the Czech side of the river.

The center of the village was the church of St. Anthony on the Glassworks Square with the adjacent Madera's inn and post office as well as the glassworks with grinding shop located opposite. Near the glassworks there was a road to a steel framed border bridge over the Dzika Orlica, where the main border crossing was located. Outside of it there were several other smaller passages through the Orlica in Lasówka, which after the war were destroyed.

In total, there were about 130 residential buildings, mostly located near the main road leading through the village, and in the vicinity of the river. Most of these buildings were small, one-story houses with walls of wooden, log frame structure sometimes with vertical planks on the outside. The livestock part of such a building was built of stone, and the whole was covered with a steep gable or mansard roof covered with shingles. Some houses had roofs covered with metal sheet or asbestos cement sheet - diamond shaped, nailed directly to the shingle. The interior of a house consisted of two parts: a living room with a large multifunctional furnace and a small bedroom, and a livestock part made of stone with rooms for cattle and fodder [Photo17]. The two parts were separated from each other by a corridor. In the attic there were residential rooms and rooms for hay. In buildings with superstructures, there were rooms for holidaymakers $(17,18)$.

After the extension of Lasówka in 1896 by the Royal Forest colony (Königswalde), located in the south-eastern part of the village, the scattered layout of the whole became even more visible. The two forester's lodges in the Royal Forest, together with another one located relatively close to the church in the central part of the village, and yet another one on the opposite - northern side of Lasówka, constituted places in the local development a few kilometers away from each other.

Surely an important attribute of Lasówka, as already mentioned, was and is its exceptionally picturesque location on the Dzika Orlica river together with the neighboring villages, forming a unique area of scattered buildings, among Sudeten meadows and forests. In the interwar period Lasówka, thanks to the construction of the Orlicka Road (Hindenburgstrasse) in 1931-32, 8 km long, and leading from the Polskie Wrota Pass through Zieleniec, to the crossroads under Hutnicza Kopa, where it connected with the Sudecka Highway running through Lasówka, gained a good connection with Duszniki -Zdrój and Kudowa. 
After the expansion of the neighbouring Zieleniec with tourist facilities and the construction of the Hindenburgbaude mountain hostel at the foot of Orlica in 1928, cross-country skiing competitions were held on the route from the aforementioned Sudeten facility through Lasówka, Mostowice, to the Spalona mountain hostel (Brandbaude). This route was more than 15 kilometers long. Tourist information was provided by a local teacher in Lasówka (14).

Just like in Zieleniec, two border guard buildings were erected in Lasówka in the 1930s. After the war they were used by WOP (Border Guard Troops) and today they are utilized as private dwellings [Photo18]. Located at the end of the development of this village, identical to the one mentioned in Zieleniec, are an example of buildings permanently and successfully becoming a key part of the surrounding landscape. It is worth emphasizing their regional form enriched with a large dormer as well as inspired by the native architecture, good proportions of the whole.

\section{After 1945}

After 1945, the Kłodzko Land, as well as the whole Lower Silesia, found itself within the borders of Poland and the Dzika Orlica became a border river between Czechoslovakia and Poland. The German population left their homes, and settlers from different parts of Poland came to their place, most of them from eastern areas of the Republic of Poland. In the first period after the end of the war, the Polish population settled the areas on the Dzika Orlica relatively smoothly and many former German farms became inhabited. At that time, community ties and good neighborliness emerged between the new settlers. This period lasted until the beginning of the 1950s, when the orders of forced collectivization of villages, which for many repatriates from the East was clearly associated with the Soviet model of economy, increased the sense of uncertainty, instability, and consequently depopulation of the border areas. In addition, there was a lack of confidence in the permanence of the post-war borders, the possibility of the return of Germans and the difficult living conditions in the mountainous region, the lack of opportunities for a wider development of tourism, including tourism in connection with areas located abroad (5).

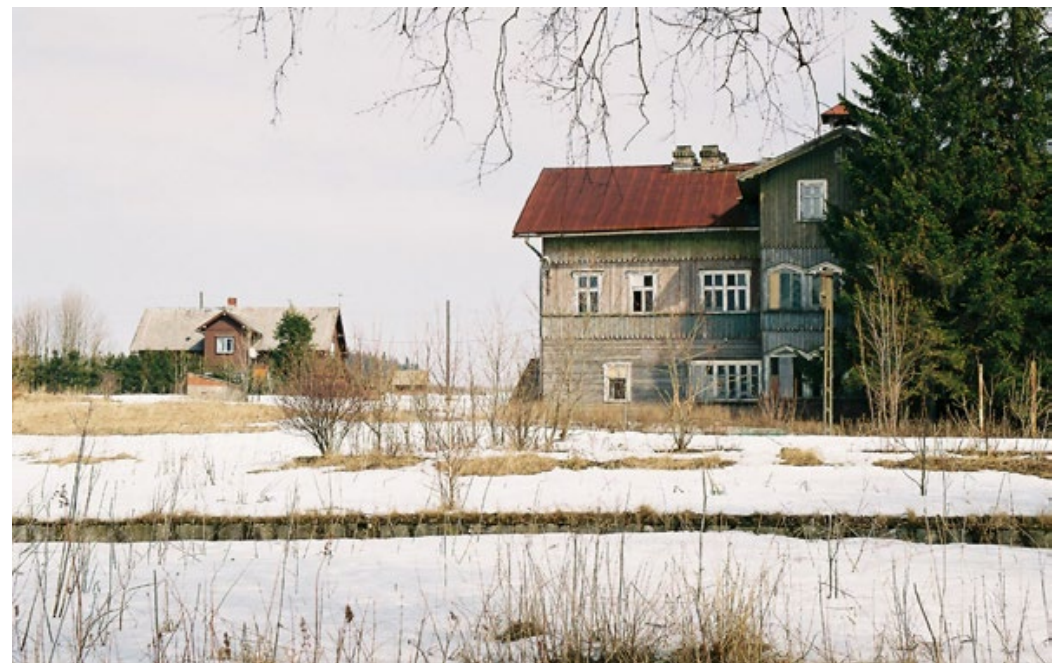

Fig. 19. The building of the former Villa Pangratz in Lasówka. After 1945 there was a colonial center here. After 2006 the building was dismantled. Photo by the author - 2006.*

Budynek dawnej Villi Pangratz w Lasówce. Po 1945 roku mieścił się tutaj ośrodek kolonijny. Po 2006 roku obiekt ten został rozebrany. Fot. autor. 2006**.

*Despite the investor's assurances about the reconstruction of the villa, there is still an empty square here today.

**Mimo zapewnień inwestora o odbudowie villi, do dziś jest tu pusty plac.

Many abandoned buildings were left empty and became degraded and ruined, some of the more appealing ones were dismantled and transported to other parts of the country. Those located on the border, i.e. right next to the Dzika Orlica, were demolished as part of the purification of the border strip in accordance with the topdown directives, which was also done on the other side of the border in Czechoslovakia. As a result, the buildings of the Wild Orlica valley, so picturesquely scattered among meadows and trees, disappeared to a large extent. 
Various branches of manufacturing existing until 1945 in Lasówka were not reborn after the war, and the largest production plant which was the glassworks was joined in 1950 to the glassworks in Szczytna and at the end of the 1950s was completely liquidated. First, in 1952, the glassworks was closed down, and then the grinding shop. To this day you can still see the foundations of the glassworks and grinding shop building opposite the church, on the other side of the road, partly overgrown with grass, and the neighboring road leading to the bridge over the Dzika Orlica. A significant fact is that immediately after the glassworks was taken over by the Polish authorities in 1945, a report was drawn up in which it was noted that the local warehouse buildings, as well as the buildings of the nearby estate were filled with glass semi-finished products, which allowed for several years of post-war production $(13,18)$.
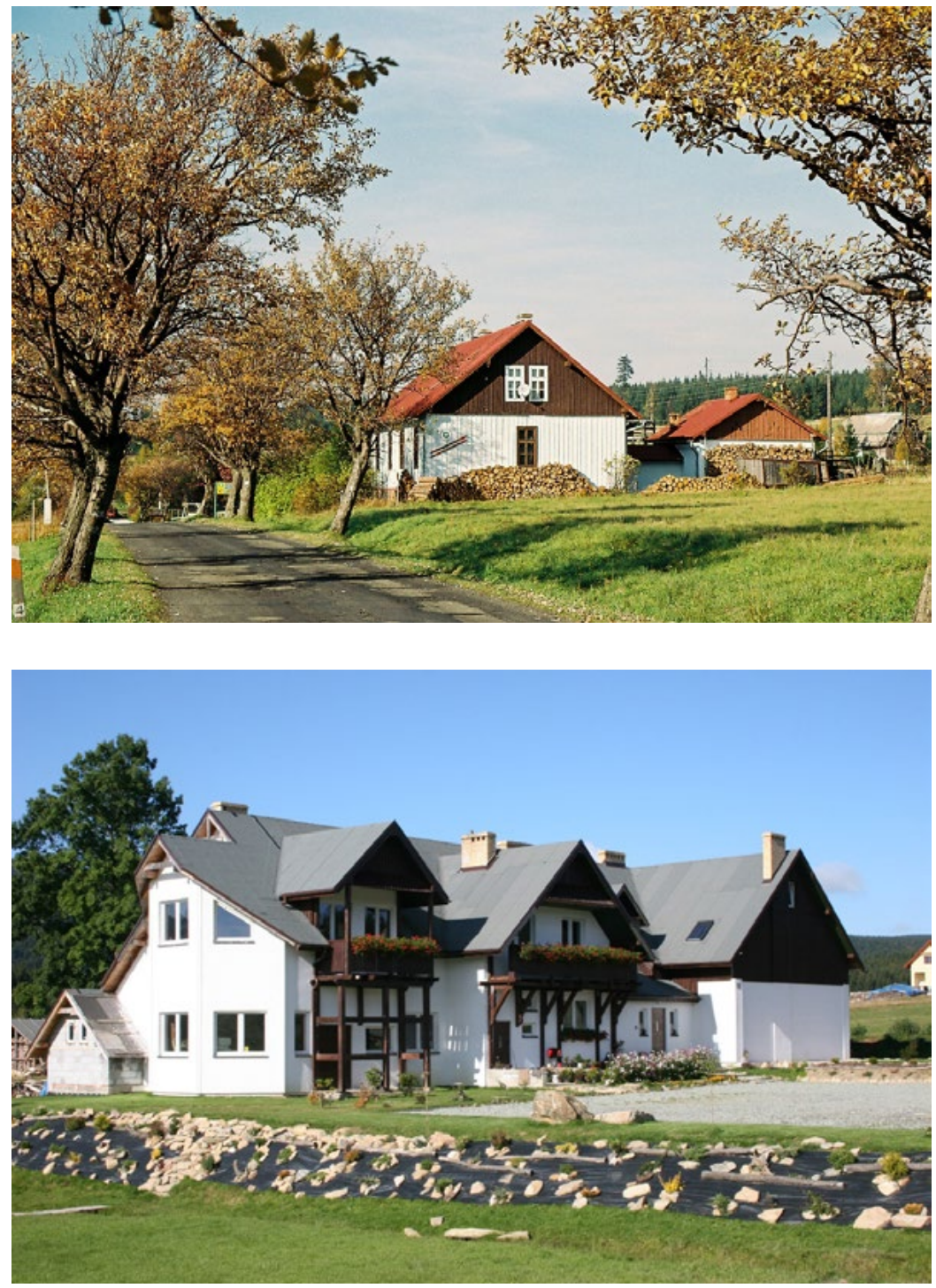

Fig. 20. The "Szarotka" hostel in Lasówka. Currently (2018) the facility is closed and will soon fall into disrepair. Photo by the author. 2006.

Schronisko "Szarotka” w Lasówce. Obecnie (2018) obiekt ten jest nieczynny i niedługo popadnie w ruinę. Fot. autor. 2006

Fig. 21. A guesthouse in Lasówka erected in 2009. In spite of the adopted style, it is difficult to find regional determinants of form here. Photo by the author - 2012 .

Wzniesiony w 2009 roku pensjonat w Lasówce. Mimo przyjętej stylistyki trudno jest tu doszukac się regionalnych wyznaczników formy. Fot. autor 2012

Also other buildings located near the glassworks, such as the school and the pharmacy ceased to exist after 1953. For some time the colonial center was the building belonging to the Pangratz family before the war (Villa Pangratz) [Photo 19]. The school was located in the later building of the Szarotka hostel [Photo 20]. After the complete liquidation of the school in Lasówka in 1978, many people left the village and moved to the city. At present (2018), it is estimated that no more than 20 to $30 \%$ of the pre-war village buildings are left. The church in Lasówka underwent repairs. Among other things, the interior was painted in 1998, and in 2001 and 

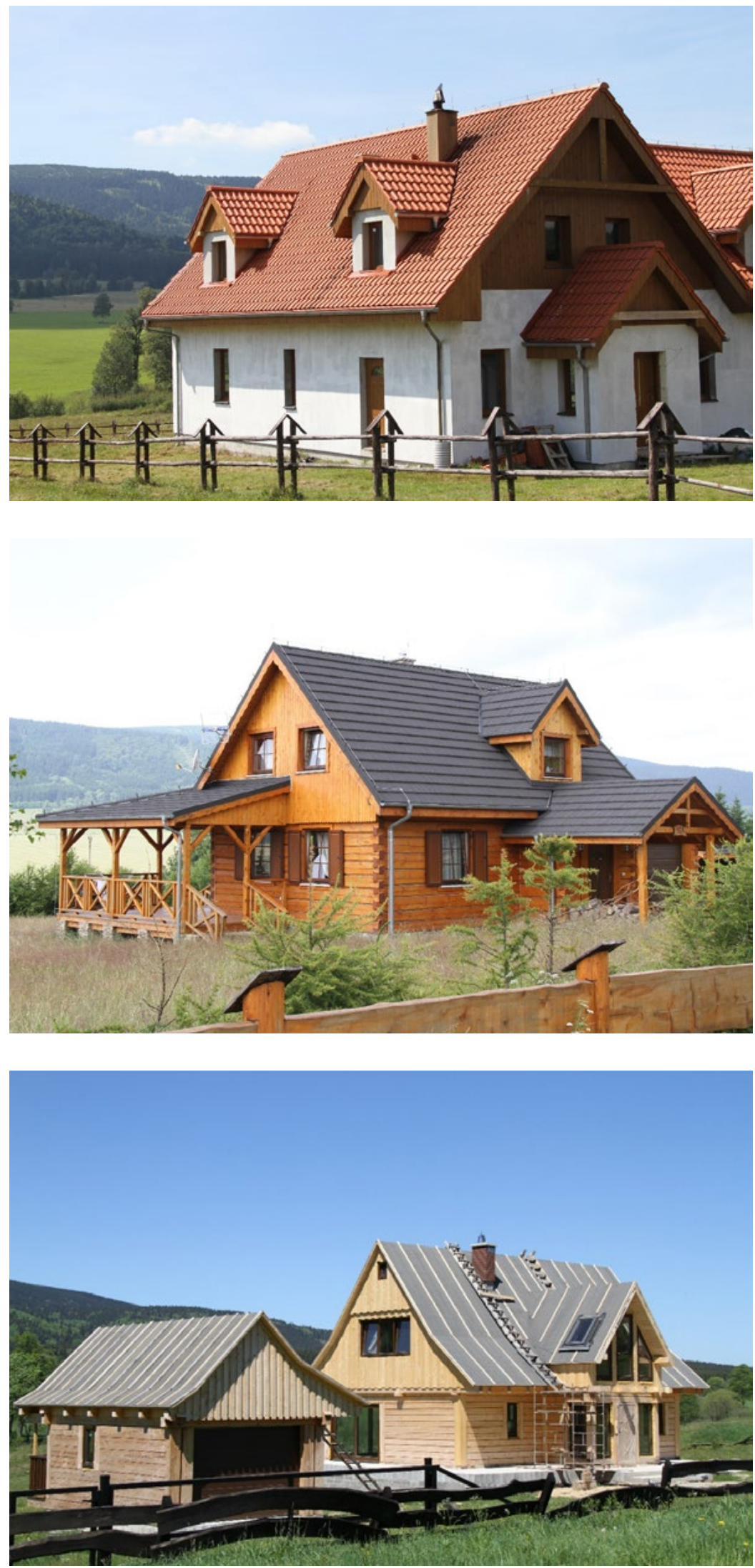

Fig. 22. One of several new residential buildings built in Lasówka, in a form devoid of regional patterns. Located opposite the closed hostel. Photo by the author -2016 .

Jeden z kilku nowych obiektów mieszkalnych powstałych w Lasówce o formie pozbawionej regionalnych wzorców. Zlokalizowany naprzeciw nieczynnego schroniska. Fot. autor 2016

Fig. 23. Lasówka. A holiday home built in 2010. Photo by the author. 2014. It is a pity that despite the wooden construction of the building and quite careful workmanship, there is a lack of regional identifiers of architecture of the Kłodzko Land. Lasówka. Dom letniskowy wybudowany w 2010 roku. Fot. autor. 2014. Szkoda iż mimo drewnianej konstrukcji obiektu i dość starannego wykonania, brak jest tu regionalnych identyfikatorów architektury Ziemi Kłodzkiej.

Fig. 24. Lasówka. A single-family building with a wooden structure and a garage under construction. It is a relatively successful attempt to refer in the architecture of the building to the regional heritage of the Kłodzko Land. Photo by the author. 2017.

Lasówka. Wznoszony budynek jednorodzinny o konstrukcji drewnianej z garażem. Jest to w miarę udana próba nawiązania w architekturze obiektu do regionalnej spuścizny Ziemi Kłodzkiej. Fot. autor. 2017. 
2002 the altars were renovated. In 2010, the metal roof and tower decking over the church were replaced with new one. Located near the church the Max Mader's inn, initially after the war was in private hands, but since 1952 was taken over by the Treasury and was demolished. After 2006, a two-storey building with a wooden structure, the so-called "colony", was also demolished. Before 1945 it belonged to the owners of the glassworks (Villa Pangratz).

The nearby locations of Piaskowice, Mostowice, Rudawa, Poniatowo or Niemojowo and Lesica succumb to a similar fate with buildings previously in good condition becoming devastated and treated as specific building material storage facilities. The main source of income for the population in Lasówka, after the war was cattle breeding and forest management works. A Production Cooperative was not established there, but other socialized units of this kind were used from nearby villages. In 1978 there were still 34 farms there, and at the beginning of the 1990s only about 10 farms (13). Currently (2018) 103 people live in Lasówka. Despite the fact that after 1945 the function of a holiday resort in Lasówka was not immediately reborn for various reasons, it was not until the second half of the $90^{\prime} \mathrm{s}$ of the $20^{\text {th }}$ century that this area witnessed some revival. The intimidating loss of pre-war building substance in the Lasówka landscape is slowly being supplemented - at least to some extent - by new buildings, mainly in the vicinity of Mostowy Potok and the western part of the village. The problem, however, remains the form and style of newly erected buildings, often differing from local, regional patterns and not different from houses built in other parts of Poland [Photo 21, 22, 23, 24] $(17,18)$. Thus, the recreational function, which is becoming more and more dominant in Lasówka - currently there are more than ten agritourism farms operating - is becoming the primary source of income for the local population [Photo 25]. Many buildings erected here by the inhabitants of Bystrzyca Kłodzka, Kłodzko and above all Wrocław, make Lasówka a fashionable and newly discovered place of outstanding landscape and climate values, with a reconstructed, modernized road connecting it with attractive tourist regions of the Kłodzko Land and the Czech Republic $(9,10)$.

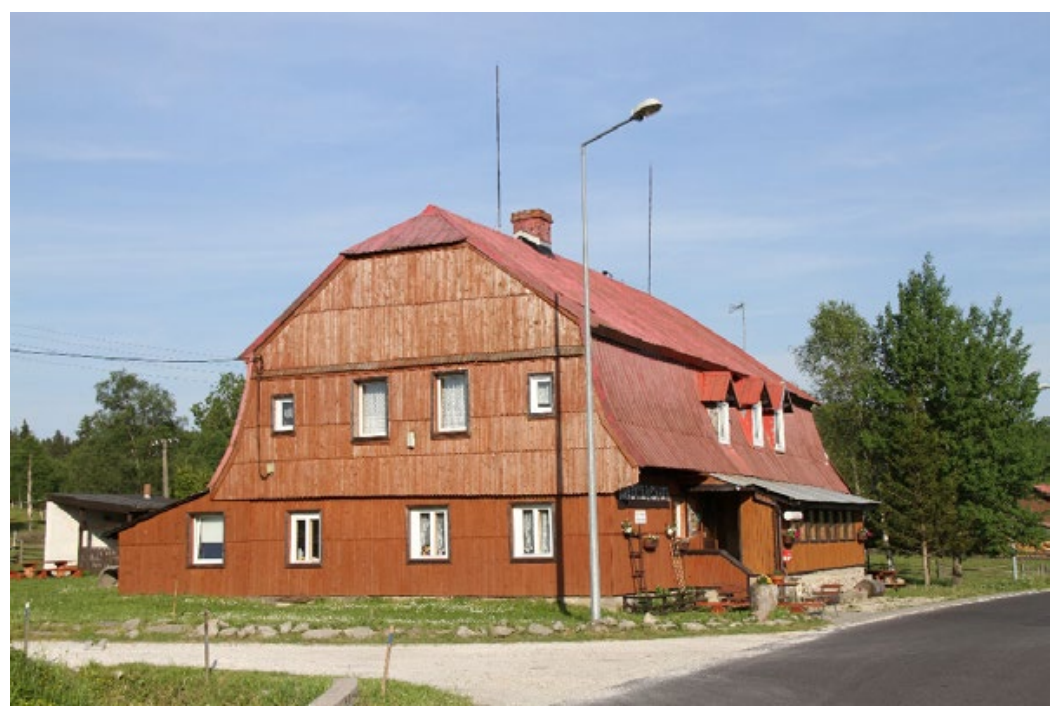

Fig. 25. Lasówka. An agritourism building, Chata Sudecka, with distinct regional features. Particularly noteworthy is the huge mansard roof, which houses a freely living story. Construction - early $20^{\text {th }}$ century. Such buildings can be found in other locations in the Kłodzko Land and on the Czech side of the border. Photo by the author - 2017 . Lasówka. Budynek agroturystyczny Chata Sudecka o wyraźnych cechach regionalnych. Zwłaszcza uwagę zwraca potężny mansardowy dach, mieszczący swobodnie mieszkalną kondygnację. Budowa - początek XX wieku. Tego rodzaju budynki występują i w innych miejscowościach Ziemi Kłodzkiej oraz po czeskiej stronie granicy. Fot. autor 2017

It is also worth noting that in Lasówka and its surroundings there are very good conditions for cross-country skiing in winter and cycling in summer.

The cycling route around the hills of Kłobuka and Biesieca, more than $20 \mathrm{~km}$ long, and a dense network of forest roads covering the surrounding vast forests are the best proof of this.

Every new initiative to make the local tourist offer more attractive is important, such as the parachute competition which took place until recently in July and which brought together a large group of interested people. Unfortunately, this competition, as well as the Szarotka hostel, have been liquidated, and the former building of the hostel is now empty and is gradually getting worse (2018).

Undoubtedly, the opportunity for Lasówka is to further expand the tourist base, not its loss. For this reason, the opening of the tourist border crossing on the Dzika Orlica river in 2015, together with the reconstruction of 
the bridge around the non-existent glassworks to Bedriichovka, should be considered as a successful project. The next initiative to reconstruct a small bridge to the Czech side over the Dzika Orlica river in 2013, opposite Chata Sudecka, is also a valuable and worthy of support. Similarly, the actions taken to commemorate the former glassworks in the form of a memorial plaque, and perhaps also a small pavilion, would certainly serve the idea of tourism development in this attractively located village.

\section{Summary}

The architecture of tourist and recreation facilities in Zieleniec and Lasówka located on the Dzika Orlica, two villages only $5 \mathrm{~km}$ apart, shows similarities and differences, resulting on the one hand from the dominant functions that have crystallized there over many years, on the other hand, the common denominator remains a strong regional tradition. In both of these centers wooden buildings of native form were created, which later became an inspiration for the built hostels, inns, guesthouses or villas. It is particularly visible in Zieleniec, where all tourist and holiday facilities erected until 1945 show more or less regional features. Lasówka was established as an industrial village and was associated with a glassworks until the early 1950 s, when the facility was liquidated. In the second half of the $19^{\text {th }}$ century it started to adopt the function of a holiday resort, offering tourists initially modest conditions for rest in small wooden houses, some of which, as time passed, became inns and hostels. In addition, there were several two-storey buildings in Lasówka with a wooden structure belonging to the owners of the glassworks, including Villa Pangratz which survived until the beginning of the 2000s.

The new buildings in Lasówka and Zieleniec, which were built after the Second World War, usually have one, visible, common feature, namely they do not refer with their form or architectural detail to the character of the local native architecture, or they do it in a clumsy way. Although recently several structures have been erected in Zieleniec and Lasówka with more successful formal solutions and better proportions of the building shape, it is difficult to talk about any clear progress here. Nowadays, it is also important that the surviving wooden, regional buildings erected until 1945, are not further degraded and are preserved in good condition for future generations, as a testimony to the beauty of regional architecture.

\section{Bibliography}

[1] Aus der Vergangenheit der Glashütte Kaiserswalde Pangratz und Co., Zu ihrem 250 jährigen Jubiläum am 13 Oktober 1906.

[2] Boguszewicz M., Rybka-Cegielska I., Wiśniewska D., Studium środowiska kulturowego gminy Bystrzyca Kłodzka woj. wałbrzyskie, Tom II, część I, Regionalny Ośrodek Studiów i Ochrony Środowiska Kulturowego we Wrocławiu,Wrocław, 1995

[3] Briegers Reiseführer, Führer durch das Heuscheuer u. Mense-Gebirge, 3 Auflage, Schweidnitz, Georg Brieger, 1912

[4] Brygier W., Dudziak T., Ziemia Kłodzka Przewodnik dla prawdziwego turysty, Pruszków, 2010.

[5] Dziedzic M., Kłodzkie Towarzystwo Górskie, 1881-1945, Quarc Studio, Wrocław, 2013.

[6] Fatyga J., Dwie wsie - jedna rzeka - trzy narody, Mostowice, Tom-1,Wydawnictwa Akademickie i Profesjonalne, Warszawa, 2009.

[7] Ferien in der Grafschaft Glatz, Ein Führer durch Kurorte, Sommerfrischen und Wintersportplatze der Grafschaft Glatz, Herausgegeben vod Dr Scholz Schriftleiter in Glatz, 1936,

[8] Festschrift zum 250 jährigen Bestehen des Dorfes, Kaiserswalde einst und jetzt, Verlag des Kapellenbau -Vereins Kaiserswalde, 1912.

[9] Gałowski M., Góry Bystrzyckie i Orlickie - Przewodnik turystyczny, Oficyna Wydawnicza „Brama”, Kłodzko, 2007.

[10] Grieben Reiseführer, Glatzer Bergland, Grieben Verlag, 1938.

[11] Hauck R., Grafschaft Glatzer Heimatblätter, 300 Jahre Kaiserswalde, Nr 6,1962

[12] Kurverein Reinerz, Neuester Führer von Bad Reinerz und Umgebung, Verlag von Georg Brieger, Schweidnitz.

[13] Mazurski R. Krzysztof, Góry Bystrzyckie I Orlickie, Sudety, Wrocław, 1993.

[14] Praca zbiorowa pod redakcją Marka Staffy, Słownik Geografii Turystycznej Sudetów, Góry Bystrzyckie i Orlickie, Tom 14, Wydawnictwo PTTK KRAJ, Warszawa-Kraków, 1992.

[15] Suchodolski J., Architektura schronisk górskich w Sudetach, Monografia,Oficyna Wydawnicza PWr, Wydanie II Poprawione, Wrocław, 2014. 
[16] Suchodolski J., Przy współpracy ze Starostwem Powiatowym w Kłodzku, Architektura Pogranicza Kłodzko-Orlickiego, Starostwo Powiatowe w Kłodzku, Wydział ZPA i B, Unigraf, Bydgoszcz, 2005.

[17] Suchodolski J, Architektura regionalna schronisk i zajazdów w masywie Orlicy, Konferencja Kłodzko-Orlicka 2005, Duszniki Zdrój 21-22.04.2005, Usługi Poligraficzne B. Kokociński, Nowa Ruda, 2005, s. 47-62.

[18] Suchodolski J., Lasówka, Ziemia Kłodzka, Grudzień 2011, nr 210, s. 24-28.

[19] Tomczak M., Orlica - szczyt zapomniany, Pielgrzymy -88, s. 77-89.

[20] Wintersportplätze der Grafschaft Glatz, Herausgegeben von Dr Scholz, Verlag Schlesischer Werbedienst, Breslau ,1936.

\section{Maps}

[1] Das Erlitztal Karte 1, Grűnborn, Friedrichswald, Trschkadorf, Kaiserswalde,

[2] Bearbeited von; Oskar und Emil Breiter, Emil Karger, Alfred Wenzel,

[3] Bürgemeister Dohnalek, Kathe Witke, Karl Wenzel, Stand 1996.

\section{Websites}

[1] www.klodzkikatek.pl, https;//pl.wikipedia.org/w/, www. wroclaw.hydral.com.pl,

[2] www.bad-reinerz.eu, www.ak-ansichtskarten.de, www.dolny.slask.org.pl,

[3] www.glatzerbergland.de

\section{Architektura obiektów turystyczno-wypoczynkowych na pograniczu kłodzko-orlickim na przykładzie Zieleńca i Lasówki}

Streszczenie: Na pograniczu kłodzko-orlickim nad Dziką Orlicą architektura regionalna wywarła duży wpływ na formę i charakter powstających tam obiektów turystyczno-wypoczynkowych do 1945 roku. Po drugiej wojnie światowej wiele tych budynków przestało istnieć. Powstające nowe nie nawiązują do bogatej spuścizny regionu, czego dowodem są pensjonaty, domy wypoczynkowe, wille czy zajazdy w Zieleńcu czy Lasówce, najlepiej rozwijających się obecnie miejscowościach tego regionu.

Słowa kluczowe: architektura, region, pogranicze kłodzko-orlickie, turystyka 